\title{
The delirium of change: Giles Deleuze's optimistic postmodernism
}

\author{
Geoffrey Wood \\ Dept. of Sociology and Industrial Sociology \\ Rhodes University \\ East London Campus \\ EAST LONDON
}

\begin{abstract}
The delirium of change: Giles Deleuze's optimistic postmodernism

Giles Deleuze's theories of domination and change represent a radical departure from both modern radicalism and the nihilism of many postmodernists. Deletuze has developed a comprehensive critique of domination within societies, and offers an alternative vision, based on the rejection of the routinized patterning of the individual's life experiences. One of his major works, Capitalism and Schizophrenia (1988) was written in collaboration with Felix Guattari. An ex-psychoanalyst, Guattari brought a specific focus to bear on the limitations of conventional approaches to therapy, its wider social implications and the alternatives thereto, a theme which is absent in Deleuze's later works. It is argued that while this vision provides a totally different alternative to many of the tired debates surrounding order and revolution, by its very nature it is limited, designed to appeal to a limited grouping of insiders, and is inadequately equipped to deal with the negative face of localised ethno-particularism which has emerged in the 1990s.
\end{abstract}

\section{Introduction}

One of the major criticisms levelled against postmodern social theory is its seeming pessimism. In contrast to the assumption of ultimate social progress which underlies much of the modernist project, postmodernism makes no claims as to the inevitability of a better life. Yet, within postmodernism there are certain key divisions, one of the most important being between the ultimately nihilist stance of thinkers such as Baudrillard, and the more optimistic vision of others, such as Giles Deleuze. This article focuses on Deleuze's conceptions of individual and collective action, and social change - an area of his writings probably of the most direct interest to the sociologist. It should be noted that this area forms but one dimension of Deleuze's extremely broad writings, and should be seen as distinct, yet related to his other studies. The latter consists of works of selected philosophers, including not only Kant and Nietzsche, but also Sacher- 
The delirium of change: Giles Deleuze 's optimistic postmodernism

Masoch, an excursus on "Alice in Wonderland" and, more recently, his monumental study of cinema, both as an art form and a reflection of social reality (Deleuze, 1989). Much of his work on oppression and change was in collaboration with psychoanalyst Felix Guattari. In these collaborative works, a major focus is on the role of conventional psychology as an instrument of social control, and alternative approaches to therapy. These issues receive less attention in Deleuze's individual works. However, in common with the individual works, the collaborative writings also cover issues of wider social order and control.

\section{Space and time}

Deleuze (1983:70) asserts that the odyssey through life is a series of lines. Firstly there is one's linear progression through a number of complementary specialised social environments, from family, to school, to the work environment, and, finally, to the infirmary. Secondly, there is the more complex molecular line. This is the line of social interactions, of one's follies and fears - a line which is ultimately reflected in one's linear progression. The third line tracks downward, of one's destination to the unknown and unexpected. It is through the recognition of these three aspects of the individual's temporal journey that personal liberation is possible.

Deleuze (1983:72) asserts that this liberation may be brought about either through "schizo-analysis" or "micro-politics". "Schizo-analysis" is the technique outlined in detail by Deleuze, in collaboration with Felix Guattari in their joint work, AntiOedipus (1983a). This work is grounded in a critique of conventional approaches to psychotherapy, drawing on Guattari's own experiences as a psychoanalyst. However, as will become apparent, Anti-Oedipus links issues concerning the individual psyche with wider social injustice, sketching a far broader critique of social reality. Some of the latter themes are carried through to Deleuze's subsequent works (which were written on his own), although the psychologicallyorientated framework outlined in collaboration with Guattari is abandoned (e.g. Cinema 2: The Time Image [1989]).

In Anti-Oedipus, Deleuze and Guattari assert that the status quo channels individuals in a specific direction in such a manner that most desire to follow it, deviance being ultimately equated with madness (Deleuze, 1989:34). It is impossible in a brief article to fully discuss the plethora of interlocking arguments and conclusions in this monumental work, much of which builds on the works of Wilhelm Reich. Acknowledging this debt, Deleuze and Guattari assert that their major departure from that theorist is that Reich still believed in the conception of rationality "as what it ought to be ... and the irrational element in desire, and by regarding only this latter as a suitable object for psychoanalytic examination" (Deleuze \& Guattari, 1983a:29). 
Basically, Deleuze and Guattari assert that conventional psychoanalysis forms an integral component of existing structures of control and domination in society, expressly designed to curb unruly social practices, rather than assist the individual. In contrast, "schizo-analysis" focuses on the social context, and the individual quest for liberation therefrom. Thus, what is considered to be mental illness, may be an individual quest for freedom, with it and "schizo-analysis" constituting a libratory form of "micro-politics". It can be argued that this approach is inherently limited. Whilst Deleuze and Guattari do supply a useful counterweight to the excesses of Freudian psychoanalysis, they do little to provide concrete guidelines for assisting those afflicted with mental illness, be it of social or biological origin, or, for that matter, those around them. Perhaps, in this area, their demolition of existing social and psychological constructs is too complete, and too little has been left to replace it. Significantly, whilst sympathetic to many of Deleuze and Guattari's arguments in this area, even Michel Foucault never took schizo-analysis seriously, or saw it as a realistic alternative to psychotherapy (Miller, 1993:282).

Although it retains a concern with the individual, a contemporary work to the first volume of Capitalism and Schizophrenia, "Politics", written by Deleuze on his own (cf. Deleuze \& Guattari, 1983a:87-102), is far more concerned with the emergent dangers in the quest for individual liberation, rather than prescribing specific strategies. Indeed, Deleuze (1983:93) concedes that the most creative and libratory of the three life lines, the molecular line, incorporates certain inherent dangers. On the one hand, there is the "black hole phenomenon" - the phenomenon of stepping over the personal edge into oblivion, as per Kurtz in Conrad's Heart of Darkness (Wakefield, 1990). On the other hand, there is the possibility of "micro-fascism", "Stalin's little groups", "neighbourhood dispensers of justice" - in other words, an extreme devolution of power, although, according to Deleuze, desirable, may itself result in domination, albeit at a more personal level.

\section{Deleuze and history}

A general problem with postmodemist social theory is that postmodernism is at once a methodological tool, a theoretical frame of reference, and a description of contemporary society (society has entered a postmodern age). In Deleuze's writings, these three issues are particularly conflated. In contrast to many other postmodern social theorists, Deleuze's perspective is broadly historical, concerned with the rise of the contemporary state. On the one hand, as the major site of repression, the state emerged at a very early stage. On the other hand, the technologies of domination are very much more advanced in contemporary society (Deleuze, 1989), making the possibility of social liberation more difficult. Thus, despite the above-mentioned historical approach, Deleuze devotes the bulk 
of his attention to a description of contemporary reality. Similarly, the solutions proposed are specifically focused on the postmodern age (see Deleuze, 1983).

\section{Territorialization and flight}

A persistent theme in Deleuze's writings is that of space and territory. Deleuze assumes that space and territory exist at three levels: at the level of physical space, in terms of the freedom-domination nexus, and, following on Foucault, in terms of the overlapping and, at times, conflicting, power networks in which the individual is enmeshed. All three levels may operate simultaneously, in a complementary and contradictory fashion. In understanding social life, Deleuze, in collaboration with Guattari (1983b:2), argues that one should not only consider the current locale of individuals and groupings within these three levels, but also how they actively resist this status, be it through deterritorialization or flight. The former is about destroying, or rendering power networks meaningless, and the latter about changing locale, seeking an alternative social reality, which may or may not be about actual physical movement. The latter, which does not presuppose the elimination of power relations, Deleuze and Guattari (1983b:5) concede is really the only feasible option. This would involve a deformalization of social relationships, with interactions being purpose-orientated, and not regulated or bound by the complexities of social norms, routines, and underlying power networks (see Deleuze \& Guattari, 1988:380). Essentially, what is being proposed is a form of anarchism, an inversion of Durkheim's concept of a developing collective consciousness underlying the routinization of socia! interactions (see Durkheim, 1933). Such an inversion presupposes that the systematization of social life is inherently repressive, and cannot be considered as social progress. Deleuze and Guattari's anarchism differs from the European anarchist tradition in that it accords no special role to any majority grouping in society such as the working class, and instead promotes the particular, the different and the mutant (cf. Sorel, 1925).

Deleuze and Guattari (1983b:5) argue that in addition to the operation and speed of flight, such radical actions also concern machinic relationships (inter alia, between the individual and social groupings), and the rather chilling concept of "bodies without organs", B.W.O. The latter concept, again, encompasses two, rather distinct, yet related meanings, both of which are closely related to earlier concepts introduced by Foucault. Firstly, there is the meaning in terms of biopower, of the individual's body within power networks. Non-compliance results in physical action being placed on the individual, either in terms of physical violence, or, more commonly in modern societies, the individual being coercively removed from the public eye, and placed under constant surveillance, as part of the dominating interests' normalising technologies (Foucault, 1979). This notion 
echoes the medieval concept of "The Man of Sorrows", of Christ's physical body bearing the strains of the world.

Secondly, there is an even darker meaning. Shortly prior to his death, in interviews, Foucault gave detailed accounts of the benefits of extreme sadomaschochistic sexual practices. Inter alia, the benefits would include the desensualization of the sexual organs and the eroticization of the entire body. This concept may seem to echo Marcuse's call for the eroticization of social life, going beyond the conventional sexual act (see Kettler, 1978:17). However, Foucault's meaning is somewhat more complex than Marcuse's. The latter held that this would entail the freeing of creative influences, and that of ushering in a new era of social harmony and creativity. To Foucault, the spreading of sensuality is also about power and domination, which will exist in all social contexts, and the pleasurable face thereof.

Deleuze and Guattari (1983a) echo Foucault's thinking in their detailed, loving descriptions of sado-maschochistic torture, involving the sewing up of bodily orifices as a path to liberation. However, their conceptions are somewhat more abstract and symbolic than Foucault's views on the matter. Deleuze and Guattari (1983a:282) assert that it represents the epitome of production, of "antiproduction", of opposition to the existing operations or workings of society. As a critique of Freudian theories, they assert that the schizophrenic's frequent claim of an inner emptiness reflects an escape from an oppressive social reality (Deleuze \& Guattari, 1983a:8), the ultimate deterritorialization and flight from the physical body itself. Sado-maschochistic torture would represent only one of a number of possible lines of flight, others of which could include forms of political action. The latter possibility is most explicitly developed in Deleuze's "solo works", when, as noted above, the strong focus on alternatives to psycho-therapy that is a feature of his collaborative works with Felix Guattari, is diluted. Thus, reflecting his close links with Maoist politics in the 1960s (see Miller, 1993:195), Deleuze (1983:87) asserts that some of the most creative lines of flight and action are in fleeing repressive adversaries, citing Mao's Long March as one such example. The Long March was not only a flight from KMT domination, but also a proving ground, and a process whereby a new political system was developed. However, Deleuze concedes that such potentially liberating actions can easily result in "reterritorialization", in new forms of repression and domination replacing the old

Interestingly, in a later joint work with Guattari (Deleuze \& Guattari, 1988:470) he asserts that micro-tribal movements, those localised nationalist movements seeking autonomy incorporate certain potentially beneficial components. They cut themselves off from the "majority", that oppressively homogeneous grouping in any society which denies individual autonomy, and, indeed, forms the basis of 
authority and domination. Recognizing such movements as a fundamental challenge to its existence, the state will seek to avoid the granting of complete local autonomy, seeking instead greater binding through a series of deals offering supposed "local government" or "devolution of power".

In 1988 Deleuze and Guattari (1988:470) argued that when all society fragments itself into groupings of minority, greater freedom is possible, "minority as a universal figure, or becoming-everybody/everything". Once minorities break free from the "plane of capital", from seeing themselves in terms of other groupings in society, it is possible to completely escape existing power networks (Deleuze \& Guattari, 1988:472). Since then, petty nationalist movements not only within Europe, but also in many areas of the developing world have proliferated. These movements do indeed constitute attempts to break away from domination by what is perceived to be an alien majority. In many cases, they represent the response to the bankruptcy of grand ideologies and the loss of meaning associated with globalization. However, few of these movements have themselves demonstrated greater tolerance, nor for that matter the rights of other minorities. In most cases, ethnic identity is defined not just in terms of a specific meaning, but also in terms of difference, in perceived superiority to others. The fragmentation of multiethnic states has often gone hand-in-hand with ethnic cleansing. It is evident that the libratory micro-tribalism espoused by Deleuze and Guattari easily mutates to new systems of domination, often little different in operation to the previous order.

\section{Power and the state}

The individual's odyssey through life implies ongoing contact with power relations, which, indeed, are a form of "over-coding mechanism" (Deleuze, 1983:78). Complex power relations and networks are in operation in society, the most important concentration being the state (Deleuze, 1983:78). The state's capacity for domination is most refined in the advanced societies, where ritualization ultimately permits the operation of a highly developed over-coding machinery. In other words, mechanisms of domination cannot ultimately control the individual's life path. However, they will seek to channel it, to shape and form it. Should the line waver from the approved path, the overcoding mechanisms come into play, seeking to redirect it into an approved path (Deleuze, 1983:80).

Deleuze and Guattari (1988:430) assert that there is no inherent reason why societies should tend to the more complex, or whether groups of small villages or towns are less advanced than states. Rather, the process of state formation is that of binding or capture, in the form of precedents, laws, and the emergence of property. "Free action ... is compared, linked, and subordinated to a common and homogeneous quality called labour" (Deleuze \& Guattari, 1988:442). It employs 
violence to contradict those who set themselves in opposition to its order, either in challenging its monopoly of violence or engaging in other forms of conduct which were legal prior to the state's seizure of dominance over society.

Although capitalism presupposes certain market mechanisms which operate independently of the state, such mechanisms are subject to "axioms", being "stopping points ... reordering ... which prevents decoded flows ... from escaping in all directions" (Deleuze \& Guattari, 1988:461). In other words, the centrifugal tendencies in capitalism, reflected in repeated crises, are contained through state intervention, an example being Roosevelt's New Deal following the 1929 Wall Street crash. In general, axioms represent low key adjustments, often responses to struggles at the localised level. In the extreme case, axioms mutate to form a "fictitious proliferation, a multiplication by subtraction" - fascism (Deleuze \& Guattari, 1988:461)

It should be noted that whilst the state's primary function is a regulating one, operating through routinized mechanisms, it coexists with the mechanism of physical coercion, "the war machine" (Deleuze, 1983:102). Although it might seem that the latter is simply an integral part of the former, the latter's role is largely destructive, and coexists uneasily with the state mechanisms dedicated towards the routinized preservation of painstakingly constructed structures of regulation and control.

In their second major joint work (in fact, sub-titled the second volume AntiOedipus), Deleuze and Guattari (1988:424) assert that the war machine indeed is exterior to political sovereignty. They assert that political sovereignty itself encompasses two poles, the "magical" leader who institutes sovereignty by means of force of personality, followed by those who regulate and institutionalise it. Once established, the state seeks to expropriate the war machine, to bring it under its sway (Deleuze \& Guattari, 1988:425), gaining a monopoly on violence. In contrast to conventional theories of the state, Deleuze and Guattari believe that this does not necessarily make society any more humane, but rather increasingly sophisticated, yet brutal mechanisms will be employed to secure authority. In the end, the means of violence is either the property of the state, and a prerequisite for its existence, or an independent centre of power opposed to it. They believe that the capture of the means of violence by a centralised state made changes in production possible and not vice versa (Deleuze \& Guattari, 1988:430). This does not mean that the war machine cannot regain autonomy, as indeed has happened in many societies in the developing world. However, this regaining does not mean a return to some primitive ideal or some "zig-zag evolution" to an inevitable conclusion. Rather, it is a temporal and spatial movement, reflecting changes in the topography of power. 


\section{Rhizomes, concealment and action}

Another persistent metaphor employed by Deleuze in his collaborative work with Guattari is that of root systems. Employing the pagan Norse image of a tree (Yggdraisal) as the centre of the world, they see the dominant root system as reflecting prevailing social reality. Modern society has multiple (radicel) roots, reflecting the multiple social influences being brought to bear on the central project. Beyond modernity is the altemative system of rhizomes, the centre of a plethora of conflicting "semiotic chains" (Deleuze \& Guattari, 1983b:11). Ideally, rhizomes should be free to expand in all possible directions. Invariably, however, social options are limited, with "deviants" being channelled back into acceptable paths (see Deleuze \& Guattari, 1983b:41). Violence is employed against those who are seen as violent - "criminals", primitives, and nomads those who challenge the existing order, the existing peace (Deleuze \& Guattari, 1988:448). Returning to the spatial metaphor, it is argued that a rhizome is a "node of plateaus", of space for free action, without beginning or end, the freedom of the nomad, that has to be understood through radically different mechanisms of analysis (Deleuze \& Guattari, 1988:53; cf. Dunn, 1991:131). This action is neither constrained nor anchored through a central taproot.

\section{Good and evil}

Deleuze's writings do not provide a clear indication of what is most desirable or progressive, and, indeed, are profoundly amoral. Indeed, it is argued that choices between, and definitions of good and evil, are simply temporary choices, which can readily be reversed. Even the will to power, as envisaged by Nietzsche, is no longer a cleansing force. Deleuze argues that in the postmodern age, in both the individual and in society, in philosophy and reality, the will to power had turned inward, had become essential suicidal (Miller, 1993:197). However, Deleuze believes that it is indeed possible to stop short of becoming a "will to nothing". It is possible to stop short of "madness and suicide", harnessing the creative side of the will to power, distilling its vital essence, "a monstrous and lawless becoming" (Miller, 1993:198).

\section{Metaphors and reality}

Deleuze employs a complex range of metaphors in his works, that both brilliantly illustrates and confuses his premises and arguments. Although these metaphors are wide ranging, they are most frequently in terms of pagan Norse belief systems, Bronze and Stone Age Western Europe, and, most commonly, the nomads of Central and Eastern Asia. In fact, Deleuze travelled rarely outside the confines of Paris, did little empirical study of nomadic society on a structured basis, his descriptions being often more fanciful than factual. Nonetheless, these parables do provide key insights into the dynamics of social life, particularly of 
the nexus between regulation, order and domination, and freedom, action and autonomy. Said (1990:2) asserts that rather than providing an abridgement and description of a particular set of social practices, Deleuze's writings represent "a concotation of brilliant work, we are unlikely to see again for a generation", a combination of a mystical aestheticism, and an analysis of the limits and possibilities of libratory politics.

Deleuze (1983:87) is critical of conventional revolutionary politics, asserting that power and desire are closely related, the desire for change often being a desire for power. This is a major reason why Deleuze's recipes for political action are somewhat opaque, and quite clearly designed for a small grouping of insiders, those who have mastered the complex forces operating on those seeking to break loose from domination. However, he does outline a revolutionary programme, orientated around localised, particularised activism.

\section{Techniques for change}

Deleuze asserts that it is possible to cast aside the state's mechanisms of domination, along with the stultifying notions of guilt, pity, logic, and reason (Miller, 1993:197). However, the appropnation of mechanisms of domination by the state does not mean that its overcoding mechanisms will always function efficiently, that "decoded flows" will cease to occur. In other words, individuals or micro-collectives can, and will continue to seek to escape the homogenizing power of the state.

Indeed, the existence of such mechanisms presupposes the existence of such flows or tendencies, although wherever possible, the state will seek to prevent them from combining or complementing each other. Essentially, one is dealing with a series of contradictions, which can be summarised as follows:

- Although seeking to overcode individuals in a uniform fashion, the state's existence presupposes the existence of decoded flows.

- The state aims to stop the unification or consolidation of these flows which are also the raison de 'être of its existence.

- Should these flows combine, new mechanisms of domination and overcoding will emerge therein. In other words, the most feasible mechanisms or organizations advancing resistance politics are in fact the least desirable.

Deleuze's conception of libratory politics is rather close to that of Michel Foucault. Essentially, Foucault argued that conventional protest movements often simply result in new forms of domination. Instead the most feasible strategy is to, by one means or another, draw attention to the plight of a particular grouping, whereafter they should be left "to speak for themselves" (Poster, 1984:147). 
The delirium of change: Giles Deleuze 's optimistic postmodernism

Foucault put these ideas into practice with his rather ineffectual penal reform grouping, GIP (Prisons Information Group).

Baudrillard has argued that in a desire to escape the legacy of Stalinism, Foucault sought solutions in anarchism, in terrorism, "and other forms of useless protest" (quoted in Deleuze, 1988:xxix; see Wakefield, 1990:134). Rejecting Baudrillard's assertion, Deleuze asserts that Foucault not only provided a comprehensive critique of the status quo, but also of Leninist vanguardism. Deleuze himself was involved in GIP in the early- to mid-1970s, at this time being one of Foucault's closest confidants (Miller, 1993:190). By introducing the notion of "outsider" into his works, as adverse to class, Deleuze argues that Foucault provided an automatic critique of Marx.

However, Foucault believed that it was still possible to create a comprehensive organization that might play a central role in bringing about real change, a notion rejected by Deleuze (1988:xxx). This difference coincided with a personal dispute between Foucault and Deleuze (over Foucault's passionate support for the state of Israel) that resulted in the two thinkers breaking off all contact until shortly before Foucault's death (Miller, 1983:282). In contrast to Foucault's views on the possibilities of organization, Deleuze and Guattari (1983a:374) assert that when "powerful organizations" emerge to represents workers, "they get nasty as soon as the nature of their aims is questioned".

Unlike Foucault, Deleuze was never a member of the French Communist Party, and his works contain far fewer echoes of the Marxist tradition. For example, there are certain parallels between the concept of "modes of production" and Foucault's "modes of information" (cf. Poster, 1984). In contrast, Deleuze's conception of history is that of overlapping and interwoven lines, linking time, space, domination and power, with no clear beginning and end (see Deleuze, 1989:98-105). However, in common with Weber, Deleuze (both individually, and jointly with Guattari) concedes the existence of certain key dates and turning points in history, most notably the emergence of the state and the war machine (Deleuze \& Guattari, 1988:430; see Weber, 1950). In addition, "there are all kinds of external circumstances that mark profound breaks" such as the rise and fall of great empires (Deleuze \& Guattari, 1988:459). However, the latter does not concern the abolition of the state, simply an alteration of its form.

\section{The limits of liberation}

As noted earlier, Deleuze recognizes the limitations of personal liberation. Although the schizophrenic is one who flees or seeks to alter an unbearable social existence, they by no means are liberated, are real revolutionaries, or possess any special insights. Indeed, the schizophrenic is one of those who have stepped over the edge, an "object of fear and horror" (Deleuze, 1983:98). While advocating 
extremist revolutionary politics, Deleuze (1983:98) expresses horror of "the madman, the addict, and the delinquent", conceding that some of the extremist solutions advocated "scare me". Many in Deleuze's immediate circle did, indeed, fall victim to drugs, madness, or the "micro-fascism" of random terrorism (Miller, 1993:198). Those who seek to marginalize themselves, will, in the end, proceed to oblivium "with only occasional micro-fascist utterings ... we are the avant garde, we are the marginalized" (Miller, 1993:98). In his desire to confine his solutions, Deleuze himself steers close to such an end. However, as Miller (1993:194) notes, in contrast to Foucault, Deleuze expressed little interest in doing, rather than simply thinking about "the unthinkable", those areas of conduct barred by society, but, potentially, the most libratory.

\section{Conclusion}

Deleuze has sketched out a comprehensive critique of contemporary social relations, suggesting a programme for revolutionary change that is radically different to the pessimism espoused by most postmodernist thinkers and the modernist radical tradition. In his collaborative works with Felix Guattari, both alternatives to conventional psychotherapy and the broader question of social liberation are explored. In his individual works, less attention is accorded to the role of conventional psychology as an instrument of social control, and much more free-ranging techniques of liberation are outlined. In common with Michel Foucault, Deleuze asserts that the individual is locked in an inherently repressive, yet faceless network of power relations, and faces constant overt or tacit coercion to remain on a set life path. As an altemative, Deleuze offers the way of the human deserter. He concedes that breaking away from the status quo may either entail delinquency and madness, or the erection of alternative and equally repressive forms of social organization. However, it is possible to bring about the deroutinization of social life, a recognition of individual and minority particularities, reducing society to a series of transactions concerned with fulfilling localised short term needs. It can be argued that Deleuze's at times fevered vision offers a totally new path to freedom and self-actualization in contrast to the over-worn solutions of much of modern radical thought. However, there is little doubt that Deleuze's alternative neither takes fully into account the potential negativities of particularism (especially apparent in the early 1990s following the collapse of Soviet rule in Eastem Europe) nor does it offer a clear blueprint or programme for liberation.

\section{Bibliography}

DELEUZE, G. 1983. Politics. ( $n$ Deieuze, G. \& Guattari, F. eds. On the Line. New York : Semiotext(e). p 87-102.)

DELEUZE, G. 1988. Foucault. Minneapolis : University of Minnesota Press.

DELEUZE, G. 1989. Cinema 2. The Time Image. London: The Athlone Press. 
The delirium of change: Giles Deleuze 's optimistic postmodernism

DELEUZE, G. \& GUATTARI, F. 1983a. Anti Oedipus Minneapolis : University of Minnesota Press

DELEUZE, G. \& GUATTARI, F. 1983b. Rhizome. (In Deleuze, G. \& Guattari, F. eds. On the Line. New York Semiotext(e). p. 2-11.)

DELEUZE, G. \& GUATTARI, F. 1988. A Thousand Plateaus. Minneapolis : University of Minnesota Press

DUNN, R. 1991. Postmodernism, Popular Culture and the Avant Garde. Theory, Culture and Society, 2(3):85-102.

DURKHEIM, E. 1933. The Division of Labour in Society. Glencoe : The Free Press

FOUCAULT, M. 1979. Discipline and Punish. Harmondsworth : Penguin.

KETTLER, D. 1978. Herbert Marcuse: The Critique of Bourgeois Civilization and Its Transcendence. (In De Crespigny, A. \& Minogue, K. Contemporary Political Philosophers. London : Methuen. p. 17.)

MILLER, J. 1993. The Passion of Michel Foucault. London : Harper Collins.

POSTER, M. 1984. Foucault, Marxism and History. Cambridge : Polity.

SAID, E. 1990. Michel Foucault: Humanistic Knowledge, Postmodern Challenges. (In Araz,

J. ed After Foucault: Humanistic Knowledge, Postmodern Alternatives. Oxford : Basil Blackwell. p. 2.)

SOREL, G. 1925. Reflections on Violence. London : Allen and Unwin.

WAKEFIELD, N. Postmodernism: Twilight of the Real. London : Pluto.

WEBER, M. 1950. General Economic History. New York : Free Press. 